\title{
Pushover Experiment of Portal Structure with Brick Wall without and with Anchor for Non-Engineered Building
}

\author{
Marsaulina Hutajulu, Isa Ansary, Johannes Tarigan \\ Civil Engineering Department, Faculty of Engineering, Universitas Sumatera Utara, Medan
}

\begin{abstract}
Based on the findings in almost all earthquakes that hit Indonesia, the damaged and collapsed buildings were simple houses built spontaneously (non engineered building), where buildings are built based on practical experience without structural calculations. One form of damage to non-structural components and structures is the relationship between columns and brick walls, where cracks and separation between columns and walls occur due to no anchor. So the design of buildings in the future is safe from the dangers of earthquakes. For earthquakes that are not too large, the building is likely to remain standing with little damage. However, to anticipate a strong earthquake and reduce the adverse effects, the building of a walled wall must be built according to the provisions of earthquake-resistant building construction by providing reinforcement in certain parts such as mounting anchors from column to wall. To find out how much influence from the installation of the anchor from the column to the brick wall, an experimental study was carried out on the walls completed with a foundation, sloof, column and beam. There were 2 specimens, namely specimen that uses the anchor and do not use anchor, so it is expected to know the behavior of mounting anchors. From the test results obtained that a pushover load of $7540 \mathrm{~kg}$ and a displacement of $56.5 \mathrm{~mm}$ for specimens using anchor while for specimens that did not use anchor had pushover $5666 \mathrm{~kg}$ and a displacement of $48 \mathrm{~mm}$. The conclusion is the installation of anchors between column and brick wall can increase
\end{abstract}

Keyword: Brick Wall, Pushover, Anchor, Non - Engineered Building

\begin{abstract}
Abstrak. Berdasarkan temuan di hampir semua gempa yang menimpa wilayah Indonesia, bangunan yang mengalami kerusakan dan roboh adalah rumah sederhana yang dibangun secara spontan (non engineered building), dimana bangunan dibangun berdasarkan pengalaman praktis tanpa perhitungan struktur. Salah satu bentuk kerusakan pada komponen non-struktur dan struktur adalah hubungan antara kolom dan dinding bata, dimana terjadi retak dan pemisahan antara kolom dan dinding akibat tidak ada angkur.. Kebanyakan bangunan yang ada dibuat pada masa yang tidak mengingatkan orang akan bahaya gempa bumi. Untuk gempa yang tidak terlalu besar, bangunan kemungkinan akan tetap berdiri dengan sedikit kerusakan. Namun untuk mengantisipasi gempa bumi yang kuat dan mengurangi dampak buruk yang ditimbulkan, maka bangunan rumah berdinding tembok tersebut harus dibangun sesuai ketentuan konstruksi bangunan tahan gempa dengan memberikan perkuatan pada bagian-bagian tertentu seperti pemasangan angkur dari kolom ke dinding sebagai salah satu perkuatan hubungan. Untuk mengetahui berapa besar pengaruh dari pasangan angkur dari kolom ke dinding bata, dilakukan penelitian terhadap dinding yang lengkap dengan pondasi, sloof, kolom dan ringbalok. Pengujian dilakukan terhadap 2 benda uji yaitu benda uji yang menggunakan angkur dan tidak menggunakan angkur, sehingga diharapkan dapat diketahui perilaku pemasangan angkur. Dari hasil pengujian diperoleh beban (pushover) $7540 \mathrm{~kg}$ dan displacement 56,5 mm untuk benda uji yang menggunakan angkur sedangkan untuk benda uji yang tidak menggunakan angkur diperoleh beban (pushover) $5666 \mathrm{~kg}$ dan displacement 48 $m m$.
\end{abstract}


Kata Kunci: dinding bata, pushover, angkur, rumah sederhana

Received 08 March 2019 | Revised 20 September 2019 | Accepted 27 September 2019

\section{Introduction}

Low-rise or non-engineered building generally consists of practical columns, beams and brick walls. However, the function of a brick wall is only a non-structural component [1] which the influence of the strength and stiffness of a brick wall often not taken into account in planning a building. In fact, brick walls are composed of brick and mortar materials that have a certain value of strength and rigidity. J. Tanjung dan Maidiawati [2] has proven that portal structure with red brick infill walls gave a significant increase in the lateral resistance of concrete structures, which can increase the lateral resistance by more than $20 \%$ and also the presence of a red brick fill wall will delay the collapse of reinforced concrete structures. From the experimental results [3] there are several designs that have been proven to be well used for nonengineered buildings, one of them is by using anchors on the beam and column where the anchor is placed on 6 layers of red brick. Damage that occurs in buildings is distinguished by structural damage in the form of damage to beams, columns, floor slabs, and foundations while non-structural damage in the form of damage to walls, ceilings, doors and windows. One nonstructural damage is damage to the walls of the building, this damage generally occurs due to the absence of anchor between the column and the wall. [4] In his research. From the results of R. Baden-Powell, E. Turang, dan R. S. W. Marthin D. J. Sumajouw [5] using the pushover analysis, it was concluded that simple dwellings with walls contribute to the stiffness that is greater than simple residences without walls.

\section{a. Earthquake Resistant Structure Planning Concept}

Indonesia which is located between 4 continental plates which are located in the earthquake-prone region. As a result of earthquakes that often occur, the existing building structure experiences vertical and lateral movements so that in the design calculation of the building structure must include safety factors that will be safe to withstand vertical forces rather than lateral earthquake forces [6]. Lateral earthquake forces directly work on parts of the structure that are not strong, causing a collapse of structural elements. In a concrete building design that must be taken into account is the ability of the structure of the building to carry the burdens that work on these structures, such as gravity and lateral loads. Gravitational load is the dead load of its own structure and living load, while those that include lateral loads are wind and earthquake loads. Referring to the earthquake-resistant building planning code [7] the design of earthquake-resistant building structure design is to prevent the occurrence of failures in each element of the structure and the emergence of casualties [8]. 
The design of structures must meet three criterias such are:

1. When a small earthquake occurs, there is no damage at all,

2. When a moderate earthquake occurs, architectural damage is permitted but not structural damages

3. When a strong earthquake occurs, structural and non-structural damages are permitted, but the damages do not cause the building to collapse

So, in anearthquake-resistant building structure design must be taken into account the effects of the cyclic lateral forces experienced by structural elements during an earthquake. In order for the structure to bear lateral forces that occur, several criteria are needed such as adequate ductility in the joint area and the use of earthquake-resistant structural elements. Therefore, in a structured design can be done by understanding the collapse scenario of the structure in carrying out the extreme burdens that work on the structure. The implementation of the structural capacity design concept is to estimate the sequence of events from the failure of a structure based on the maximum load experienced by the structure. So that we plan buildings with structural elements not made as strong as the planned style, but there are structural elements or points on the structure that are made weaker than the others in hopes of that element or point that structural failure occurs when the earthquake loads maximum work.

\section{b. Wall filler}

The infill wall used in this study is a red brick wall, this is because red brick has a price that is economical, easily available and weather resistant and is widely used in buildings in the territory of Indonesia [9] Brick fill walls are commonly used in reinforced concrete structures or steel structures. Walls can be used entirely on building walls and some have openings for doors and windows. But in a building structure design, the infill wall is only needed as a partition without structural functions. Meanwhile, damage to the wall can affect the rigidity of the building which results in damage to the structure. [8].

\section{c. Standard Requirements for Bricks}

1. Redbrick made of clay which is opened, then burned. Not all clay can be used. It only consists of certain content of sand (silica).

2. Generally has a size: $17-23 \mathrm{~cm}$ long, $7-11 \mathrm{~cm}$ wide, $3-5 \mathrm{~cm}$ thick.

3. Weighing an average of $3 \mathrm{~kg} / \mathrm{seed}$ (depending on the brand and area of origin).

4. The raw material needed for red brick wall pairs is cement and sand sieve. For watertight walls a mixture of 1: 2 or 1: 3 is needed (meaning, 1 dose of cement is 
combined with 3 doses of sand that have been sifted). For walls that do not have to be waterproof, a ratio of 1: 4 to 1: 6 can be used.

5. The excellence of red brick walls: Water resistant so that infrequent seepage occurs due to rainwater, cracks are relatively rare, strong and durable, the use of concrete frames is wider, between 9-12 m2.

6. The drawback of red brick walls: Installation time is longer than brick and other wall materials, the cost is higher when compared to brick.

Brick compression Strength Test Formula:

$$
\mathrm{F}=\frac{P}{A}
$$

Where:

$$
\begin{array}{ll}
\mathrm{F} & =\text { Compressive strength }\left(\mathrm{kg} / \mathrm{cm}^{2}\right) \\
\mathrm{P} & =\text { Load received }(\mathrm{kg}) \\
\mathrm{A} & =\text { Cross-sectional area }\left(\mathrm{cm}^{2}\right)
\end{array}
$$

7. The standard compressive strength of bricks required by [10] is $10.40 \mathrm{MPa}$. Redbrick quality can be classified into 3 levels, namely:
a. Level I has an average compressive strength of $>100 \mathrm{~kg} / \mathrm{cm}$.
b. Level II has a compressive strength of between $80-100 \mathrm{~kg} / \mathrm{cm}$.
c. Level III has compressive strength between $60-80 \mathrm{~kg} / \mathrm{cm}$.

8. Requirements for bricks or red bricks according to [11] and [12] are as follows:

a. The standard form of brick is a long rectangular prism, angled and sharp, flat surface and not cracked.

b. Standard size: According to [12]

Module M-5a: 190 x 90 x 65 mm

Module M-5b: 190 x 140 x 65 mm

Module M-6 : 230 x 110 x $55 \mathrm{~mm}$

9. According to [13]:

Length: $240 \mathrm{~cm}$

Width: $115 \mathrm{~mm}$

Thickness: $52 \mathrm{~mm}$

10. Deviation in size allowed according to [13]

Maximal length: 3\%

Maximum width: $4 \%$

Maximum thickness: 5\%

Brick is divided into 6 strength classes which are known from the large compressive strength, namely: class 25 , class 50 , class 150 , class 200 and class 250 . 


\section{Research methods}

\section{a. Material}

The materials needed in making these test objects include: Cement, Sand (fine aggregate), Gravel (coarse aggregate), Iron / Steel Reinforcement, Brick, Water, Wood.

\section{b. Equipment}

Test specimen that has been prepared will be tested. The dial indicator is placed at both ends of the top, and so is the hydraulic jack. The evaluation process is to give lateral to the top end of the portal by describing the load at the end until the test object is destroyed or recaptured. Adding a load of 100 Psi until the load is destroyed. So that the load given is even, a steel plate is used as a relief plate in detail. Observations in the test load and bring back the pattern that occurs in the test object due to load. Test planning can be seen in Figure 1.

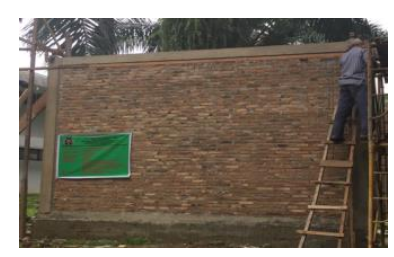

Figure 1. Complete Test Equipment

\section{c. Hydraulic Jack}

The equipment to be used in testing is Hydraulic JackThis tool has a loading capacity of 6000 Psi, carrying out a pushing motion that aims to give the sample weight. This tool is shown as in Figure 2.

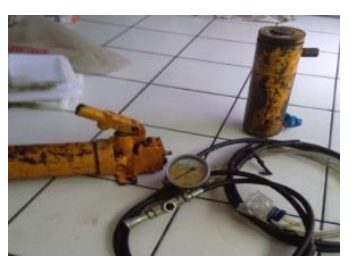

Figure 2. Hydraulic Jack

\section{d. Dial Indicator}

This tool has an accuracy of $0.01 \mathrm{~mm}$ and will be used to measure displacement in the test object. This tool is shown as in Figure 3.

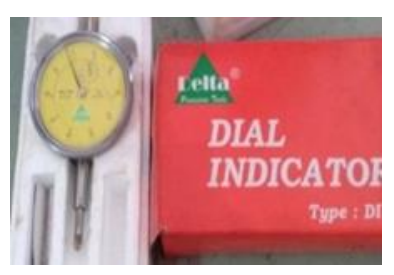

Figure 3. Dial Indicator 


\section{e. Turtle Tool}

This tool is designed with artisan direction so that the Dial Indicator can be placed in a stable position and the results of the Dial Indicator reading are accurate. This tool as shown in Figure 4.

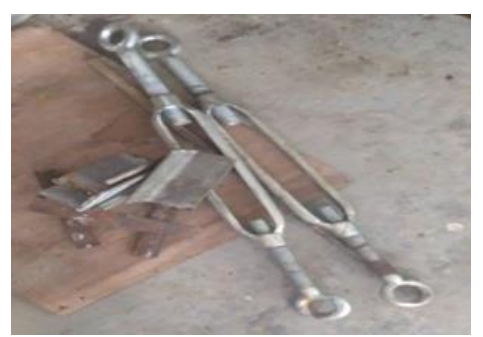

Figure 4. Turtle Tool

How to display the Dial Indicator with my turtle is designed so that the needle from the Dial Indicator is read, as shown in Figure 5.

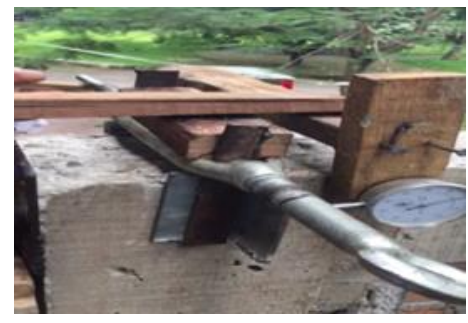

Figure 5. How to install Dial Indicator and Turtle

\section{f. Steel Profile $\mathbf{H}$}

This tool is useful as a Hydraulic Jack tool holder so that the length of Jack Hydraulic meets the needs. This tool can be seen in Figure 6.

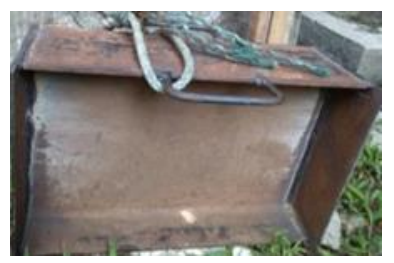

Figure 6. H steel profile

The distance between the existing wall and the test object is $120 \mathrm{~cm}$, while the Hydraulic Jack is approximately $30 \mathrm{~cm}$ long. So to help Hydraulic Jack get to the test object a tool in the form of a beam $\mathrm{H}$ with a length of $90 \mathrm{~cm}$ is needed in such a raft so that the load can push the test object and read the dial more accurately. The Dial Indicator reading is carried out every 100Psi fix. Then the installation of Hydroulik and Dial Indicator Jacks must be perfect. The installation of these tools can be seen in Figure 7. 


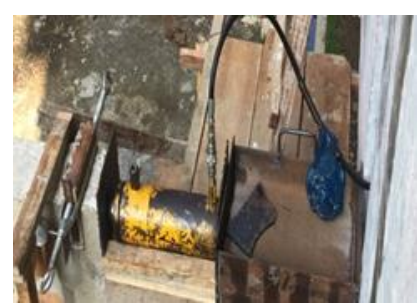

Figure 7. How to install turtles and Dial Indicator

\subsection{Experimental Procedure}

The specimen to be tested later is a wall complete with sloof, column, ring wall. This test will be carried out on 2 specimens, namely:

- The specimen that Using Transport from Columns to Walls and from Beams to Walls. [14]

- Specimen Transfers from Columns to Walls from Beams to Walls

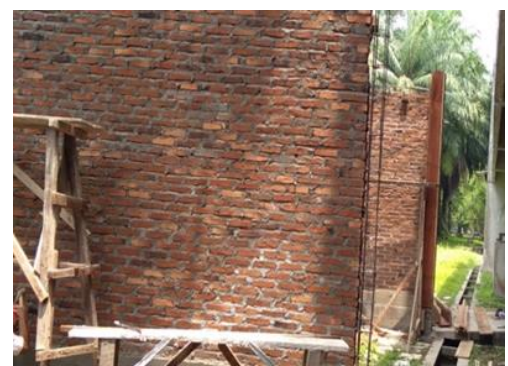

Figure 8. Using anchor and not using anchor

The size of the specimen is $3.0 \mathrm{~m} \times 4.0 \mathrm{~m}$. The working procedures in making these specimens are as follows:

a. The test object is made, directly placed on the ground which previously made the foundation as a sloof so that the test object is not lifted during testing.

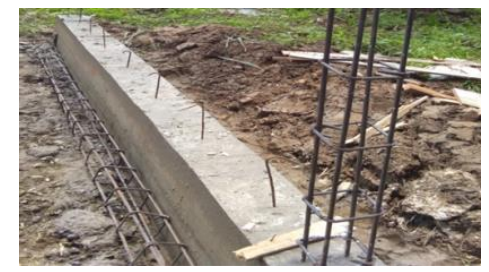

Figure 9. Foundation after being casted

b. The next step is to assemble sloof, column, beam and anchor reinforcement. The detail of reinforced concrete elements are used as shown in Figure 9. 


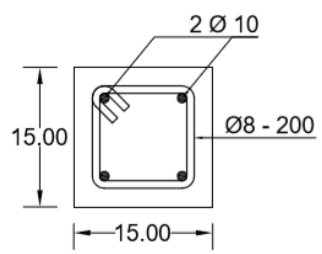

$\underline{\text { SLOOF } 15 \times 15 \mathrm{CM}}$

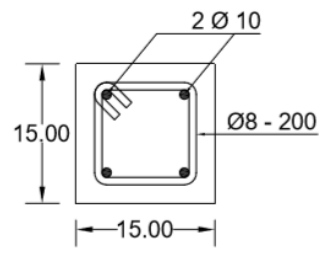

$\frac{\text { KOLOM } 15 \times 15 \mathrm{CM}}{\text { SKALA 1:50 }}$

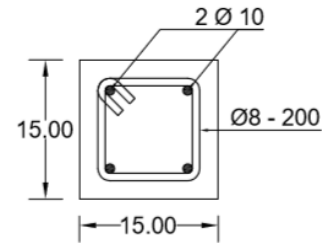

RING BALOK $15 \times 15 \mathrm{CM}$

Figure 10. Reinforcement of sloof, column, and ringbalk

The stirrup must have a seismic hook (bend) along 6D, as shown in Figure 11 :
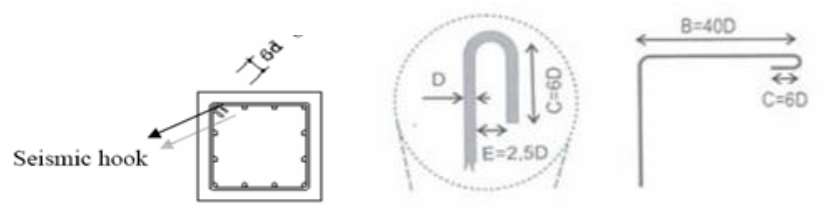

Figure 11. Cross stirrer

c. The next step is Sloof, which includes:

d. Making sloof formwork.

e. Assembling sloof reinforcement with column reinforcement (made using anchor/cuttings and not using anchor).

f. Casting of sloof, for mixing concrete using a ratio of 1 cement: 2 sand: 3 gravel

g. After the sloof dries, the next step is brick wall work, with mortars (species) used as thick as $1 \mathrm{~cm}$ and a comparison of 1 cement: 4 sand.

h. After the work of the brick wall is finished and has dried up, the next step is column and ringbalk work which includes:

> Arranging column reinforcement with ringbalk reinforcement, for corner connections between columns and ringbalk can be seen in the following figure 12 .

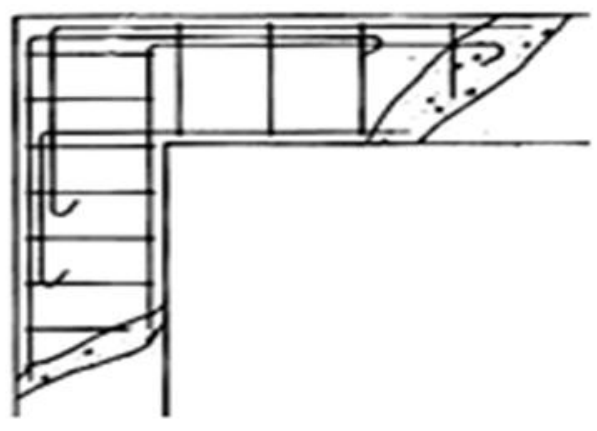

Figure 12. Reinforcement of the beam and column ring joints

Making column formwork and ringbalk.

> Column casting and ringbalk are carried out simultaneously or together, for the concrete mixture also use a ratio of 1 cement: 2 sand: 3 gravel, as in figure 13 . 

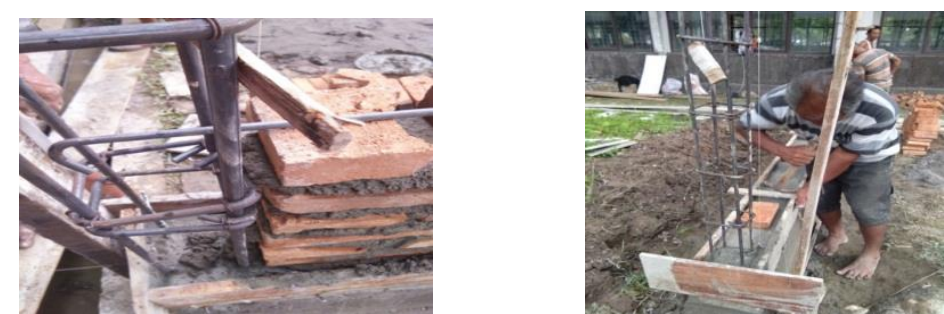

Figure 13. Angkur Installation Details

\section{Analysis And Discussion}

From the results of the tests carried out the results obtained as in table 1 below:

Table 1. Experimental Data on Test Items Using Anchor (Cuttings). [14]

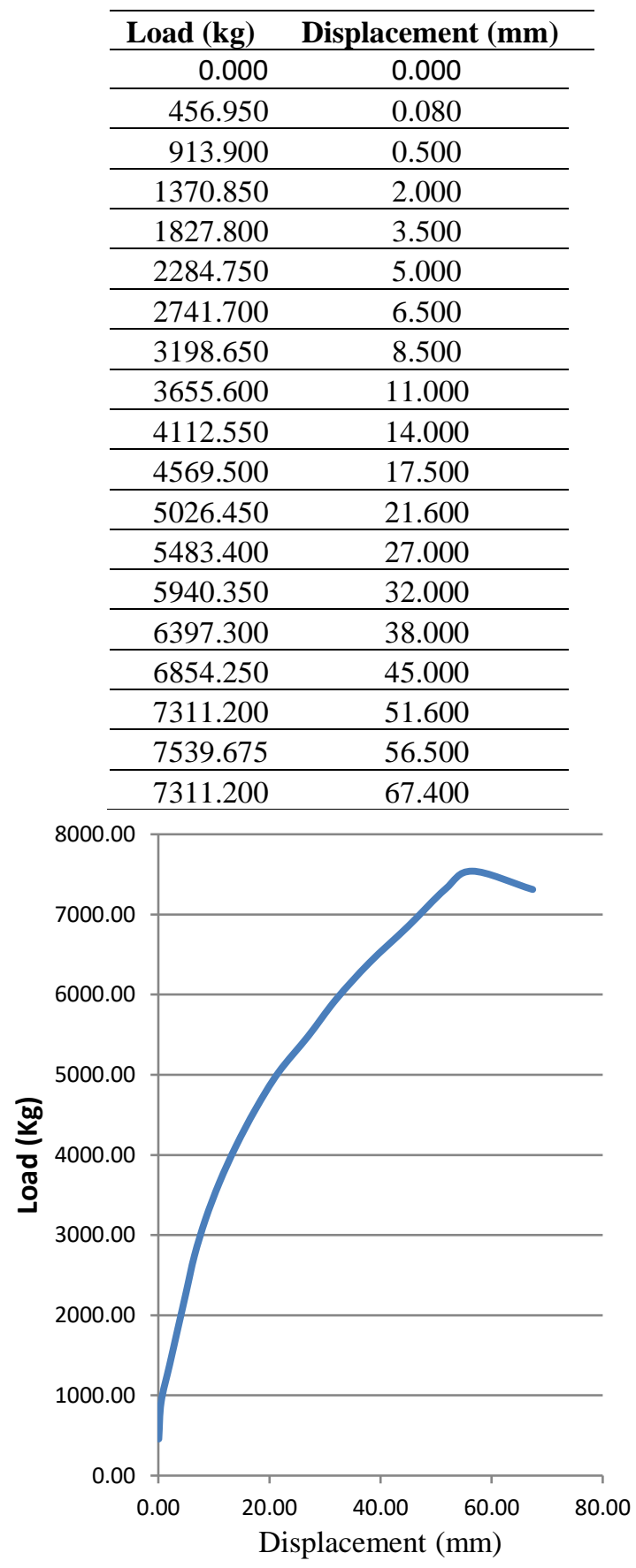

Figure 13. Load vs Displacement 
Table 2. Experimental Data on Test Items that Do Not Use Anchors

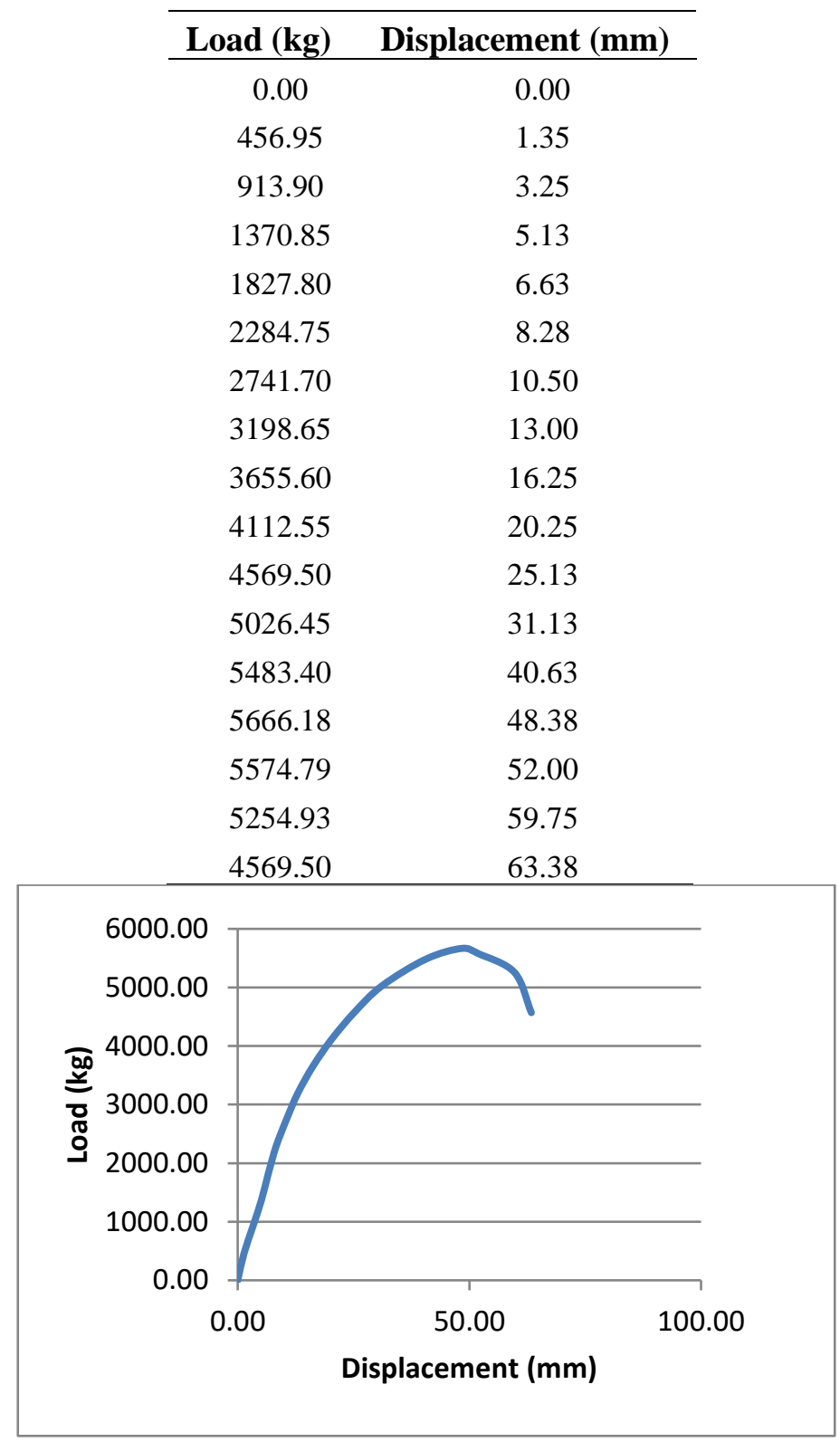

Figure 14. Load vs Displacement

To see the difference between the graphs of the two test objects, see Figure 15 below:

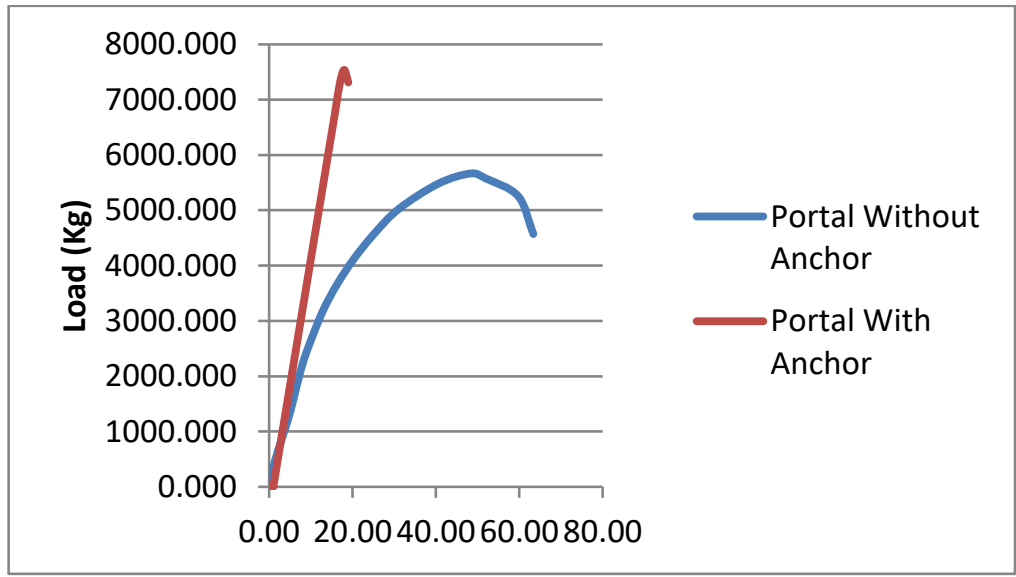

Figure 15. Combinations of the Two Specimens 
Early Cracks

a) The first crack on the specimen that uses an anchor and which does not use anchor occurs at the end of the beam.

b) The first crack which is characterized by a nonlinear load curve with displacement due to a pushover load of $456.95 \mathrm{~kg}$ for those using an anchor and not using anchor, the specimens had the same first crack load.

c) The displacement that occurred in this first crack was $0.08 \mathrm{~mm}$ for those using an anchor and those who did not use anchor $1.35 \mathrm{~mm}$.

Early yielding

The beginning of yielding occurs after the concrete in the column has cracked and the reinforcement begins to yield. At the beginning of yielding occurs at pushover load of $6854 \mathrm{~kg}$ for that using anchor and $5026.45 \mathrm{~kg}$ for those who do not use anchor. The displacement that occurred at the beginning of this yielding was $45 \mathrm{~mm}$ for those using anchor and $31.13 \mathrm{~mm}$ for without anchor

Ultimate

a) Ultimate occurs when the load that the portal is capable of carrying is the maximum load.

b) When the ultimate occurs due to pushover load of $7539,675 \mathrm{~kg}$ for those using anchor and $5666.18 \mathrm{~kg}$ for those who do not use anchor.

c) The displacement that occurs in the ultimate moment is $56.5 \mathrm{~mm}$ for those using anchor and $48.38 \mathrm{~mm}$ for those who do not use anchor.

Failure

a) This occurs when the load no longer increases and the concrete starts to disintegrate.

b) To the failure, loads are $7311.20 \mathrm{~kg}$ for that using anchor and $5574.79 \mathrm{~kg}$ for that without anchor.

c) The displacement that occurred during the destruction was $67,400 \mathrm{~mm}$ for that using anchor and $52.00 \mathrm{~mm}$ for that without anchor.

\section{Conclusion}

Based on the research that has been done, it can be concluded that:

1. The specimen using anchor produced a diagonal crack pattern but did not allow the brick wall to separate from the column.

2. Test specimen without anchor produced diagonal crack patterns which resulted in a separation between brick walls and columns.

3. Installation of anchors from the column to the wall can increase the strength of the connection between brick walls and columns.

4. From the results of experiments conducted in the field, the ultimate load value was $7539.68 \mathrm{~kg}$ with $56.5 \mathrm{~mm}$ displacement for specimen using anchor while specimen 
without anchor had the maximum load value was $5666.18 \mathrm{~kg}$ with displacements of $48.38 \mathrm{~mm}$.

5. The connection between the wall recognition column and the wall using anchor $\varnothing 8 \mathrm{~mm}$ in length $30 \mathrm{~cm}$ per 6 layers of brick.

6. The main principle of earthquake-resistant buildings is the existence of a unit of the building structure, all elements work together as a whole, so it does not work separately.

\section{REFERENCES}

[1] SNI-03-1726, "Tata Cara Perencanaan Ketahanan Gempa untuk Bangunan Gedung," 2002.

[2] J. Tanjung, "Studi Eksperimental tentang Pengaruh Dinding Bata Merah Terhadap Ketahanan Lateral Struktur Beton Bertulang 2 . Pengaruh Dinding Terhadap Perilaku," vol. 23, no. 2, pp. 99-106, 2016.

[3] D. Prevention, "Experimental Study on Confined Brick Masonry in Indonesia," 2004.

[4] F. A. Ismail, "Studi pengaruh pemasangan angkur dari kolom ke dinding bata pada rumah sederhana akibat beban gempa," vol. 6, no. 1, pp. 37-44, 2010.

[5] M. D. J. Sumajouw, R. S. Windah, F. Teknik, J. T. Sipil, U. Sam, and R. Manado, "ANALISA PORTAL DENGAN DINDING TEMBOK PADA RUMAH TINGGAL SEDERHANA AKIBAT GEMPA,” vol. 2, no. 6, pp. 310-319, 2014..

[6] S. Frapanti, J. Tarigan, S. Pengajar, F. Teknik, S. Pengajar, and U. S. Utara, "ANALISA PORTAL YANG MEMPERHITUNGKAN KEKAKUAN," 2017.

[7] B. P. Armstrong, "1997 Uniform Building Code to 2006 International Building Code Cross Reference Table Chapter 1 : Administration," hal. 1-44, 2006.

[8] M. Titono, "Analisa Ketahanan Gempa Dalam Rangka Konservasi Bangunan Bersejarah, Studi Kasus: Gedung X," Universitastas Indonesia, 2010.

[9] Mizanuddin Sitompul, "Evaluasi Daktalitas Struktur Beton Bertulang Akibat Pengaruh Dinding Pengisi Bata Merah," J. Educ. Build. Build., vol. 3, no. 2, hal. 12-16, 2017.

[10] ASTM C67-03, "Standard Test Method for Sampling and Testing Brick and Structural Clay Tile," 2001.

[11] Peraturan Umum Untuk bahan Bangunan di Indonesia (PUBI-1982), "Direktorat Penyelidikan Masalah Bangunan, Bandung," 1982.

[12] Departemen Pekerjaan Umum. 1978, Mutu dan Uji Bata Merah Pejal (SII-002178).Bandung: Yayasan Lembaga Pendidikan Masalah Bangunan. 1978.

[13] B. merah sebagai bahan bangunan NI-10, ASTM C67-03a_. 2011.

[14] M. Hutajulu, "Analisa Pushover Dan Esperimen Struktur Portal Dengan Dinding Batubata Menggunakan Angkur Pada Kolom Dan Balok Untuk Non Engineered Building," Universitas Sumatera Utara, 2018. 